\title{
Phytomicrobial Dietary Treatment Improves Growth Indices of Pigs
}

\author{
JI Ugwuoke ${ }^{1}$, CA Nwankwo ${ }^{2}$ and CE Dim ${ }^{1 *}$ \\ ${ }^{1}$ Department of Animal Science, University of Nigeria, Nsukka, Nigeria \\ ${ }^{2}$ Department of Animal Science and Technology, Nnamdi Azikiwe University, Awka, Nigeria \\ *Corresponding author: chinonso.dim@unn.edu.ng
}

\begin{tabular}{|c|c|c|}
\hline Article History: $21-381$ & Received: 25 -Aug-21 & Accepted: $11-O c t-21$ \\
\hline \multicolumn{3}{|l|}{ ABSTRACT } \\
\hline $\begin{array}{l}\text { The growth and body mo } \\
\text { garlic powder }(\mathrm{GP}) \text { was ir } \\
\text { in allocating landrace pig } \\
\text { fed basal diets improved } \\
\text { T4, } 50 \mathrm{~g} \text { each of LA and } \\
\text { determined. Daily record } \\
\text { (FCR). Morphological m } \\
\text { a bi-weekly basis till the } \\
\text { 3.41) to be significantly } \\
\text { 3.79). HW was superior i } \\
\text { was better }(\mathrm{P}<0.05 \text { ) tha } \\
\text { Consequently, we conclu } \\
\text { growth performance of } \\
\text { bulkiness to accomplish } \mathrm{s}\end{array}$ & $\begin{array}{l}\text { metrism of weaned pigs on dietary treatment with } \\
\text { orated in a sixteen-week study. The experiment adop } \\
=24) \text { to four discrete dietary treatments, tagged (T1- } \\
\text { phytomicrobial treatment using LA and GP, i.e., T } \\
\text { 5hog- } 1 \text { diet. Pigs were fed } 4 \% \text { of their body weight } \\
\text { eed intake (ADFI) and weight gain of test pigs calcu } \\
\text { ements of pig's height at withers (HW), chest girth } \\
\text { letion of the study. Data generated and analyzed pres } \\
\text { rent }(\mathrm{P}<0.05) \text { from T1 }(1.44 \mathrm{~kg} ; 4.97) \text { but similar to } \\
(53.00 \mathrm{~cm}) \text { yet inferior }(\mathrm{P}<0.05) \text { in } \mathrm{T} 1(47.54 \mathrm{~cm}) \text { and } \\
(75.02 \mathrm{~cm}) \text { alongside wider CG }(72.33 \mathrm{~cm}) \text { than } \\
\text { hat phytomicrobial dietary treatment using } 50 \mathrm{~g} \text { each } \\
\text { g pigs while } 50 \mathrm{~g} \text { LA } / 50 \mathrm{~kg} \text { diet increased morph } \\
\text { ior body morphometrism of the pigs. }\end{array}$ & $\begin{array}{l}\text { cillus acidophilus (LA) and } \\
\text { mpletely randomized design } \\
\text { replicated thrice. Pigs were } \\
\text { 1; T2, 50g LA; T3, 50g GP; } \\
\text { their weekly weights were } \\
\text { r feed conversion efficiency } \\
\text { d body length (BL) were on } \\
\text { DFI and FCR of T4 }(1.16 \mathrm{~kg} \text {; } \\
6 \mathrm{~kg} ; 3.60) \text { and T3 }(1.25 \mathrm{~kg} \text {; } \\
17 \mathrm{~cm}) . \text { BL of T2 }(81.08 \mathrm{~cm}) \\
\text { T4 }(67.46 \text { and } 65.02 \mathrm{~cm}) \text {. } \\
\text { nd GP } 50 \mathrm{~kg}^{-1} \text { diet improved } \\
\text { dimensions for height and }\end{array}$ \\
\hline
\end{tabular}

Key words: Direct fed microbial, Body morphometrism, Landrace, Spice feeding.

\section{INTRODUCTION}

Pig production has shown to be proficient in ameliorating the nutrient deficiencies of mans' diet due to inherent biological characteristics that furnished the animal's survivability in nature (Umeh et al. 2015; Obayelu et al. 2017; Morenikeji et al. 2019). Consequently, pig production has experienced significant improvement through the incessant exploitation of several dietary strategies observed in trial and practice (Wang et al. 2018; Pomar and Remus 2019; Blavi et al. 2021). Nonetheless, natural feed enhancers were published as ideal feed agents in augmenting production of domestic animals without adverse implications (European Food Safety Authority [EFSA] 2017). Thus, a number of non-toxic feed additives have been incorporated in swine feeding to improve performance features of pigs. They include but not limited to; aromatic botanicals, live bacterial organisms, organic acids, oregano products, and non-nutritive by-products (Suryanarayana and Durga 2018; Widayati et al. 2018; Schubert et al. 2021).

So far, aromatic botanicals popularly known as spices are preferred among animal producers due to the limited side effects, minimal administration costs and wide range of effects observed with their usage (Sanchez et al. 2020). Garlic (Allium sativum) is the amaryllidaceous spice that has served cooking and therapeutic purposes before the contemporary use in boosting performance indices of food animals attributable to the constituent allicin. Allicin of garlic have proved to improve the health and performance of pigs by conditioning their gut features for efficient utilization of feed nutrients (Upadhaya and Kim 2017). Moreover, feed use of live microorganisms (probiotics) in livestock production was designated "generally recognized as safe" (GRAS) and best suited dietary alternative for enhanced performance of farm animals by the United States Food and Drug Administration (Plavec and Berlec 2020). The most dominant effect of probiotics in promoting performance of farm animals involves the significant inclination of gut microbes towards the lactic acid bacteria, particularly the Lactobacillus species (Dowarah et al. 2017). These acid-loving bacteria exhibit inimitable beneficial features in the animals' GIT that have poised their preference over most probiotic microorganisms used in animal feeding.

Cite This Article as: Ugwuoke JI, Nwankwo CA and Dim CE, 2022. Phytomicrobial dietary treatment improves growth indices of pigs. International Journal of Veterinary Science 11(2): 257-263. https://doi.org/10.47278/journal.ijvs/2021.105 
However, the quest to increase food animal production still subsists, taking into account the extant limited food resources available to the ever-rising population of human beings estimated to surpass 10 billion people by 2050 (United Nations Department of Economic and Social Affairs [UNDESA] 2019). This alarming situation has called for global concern as it threatens a safe future for all mankind. In view of this, experts have geared-in research efforts lately to proffer sustainable ingenious interventions that will surety food security for every human being living on the planet, both now and in the future.

Meanwhile, the scarce literature on phytomicrobial treatment of pig diets using Lactobacillus acidophilus together with garlic spice to influence the animal's growth and body morphometrism on the same experimental field justified our present study. Body morphometrism are straight line measurements of the different body extremities of an animal which are used to predict the live weight of an animal and consequently its growth. The growth performances of animals have been used to estimate their production (Adeola et al. 2013; Kumari et al. 2020). Hence, the present experiment assessed the growth performance and body morphometrism of pigs served diets improved with Lactobacillus acidophilus and garlic powder on the same experimental farm conditions.

\section{MATERIALS AND METHODS}

\section{Location and Duration of Study}

The experiment was conducted at the Piggery Unit, Department of Animal Science Teaching and Research Farm, University of Nigeria, Nsukka. The geographical location of Nsukka lies within latitudes $6^{\circ} 43^{\prime}$ and $7^{\circ} 00^{\prime}$ north and longitude $7^{\circ} 13^{\prime}$ and $7^{\circ} 35^{\prime}$ east at elevation of $551.68 \mathrm{~m}$ above sea level, with a tropical climate having adequate sunshine all year round (Onyenucheya and Nnamchi 2018). The duration of the experiment was 16 weeks.

\section{Management of Animals and Feeding}

Before the setup of the study, experimental concretefloored pens $(n=12)$ measuring $3.2 \times 2.7 \mathrm{~m}$, were thoroughly washed and bared without stocking. The pens had low walls to aid adequate ventilation while solar bulbs served as source of illumination in the pig house. Test pigs were allowed 14 days of pre-experimentation, during which they were de-wormed, acclimatized, and fed basal diets prepared according to NRC (2012) recommendation for weaned piglets (Table 1) on ad libitum basis. The treatment materials were garlic (Allium sativum) and Lactobacillus acidophilus, sourced from Department of Animal Health and Production, University of Nigeria, Nsukka. The garlic bulbs were trimmed of all accessories and spread on clean floors to dry (14 days) before milling to powder. The garlic powder (GP) was sieved into plastic containers with airproof covers and kept in a cool dry room. The test microbial was $1.0 \times 10^{10} \quad \mathrm{CFUg}^{-1} \quad$ spray-dried Lactobacillus acidophilus (LA) prepared in sterile sample bottles $(100 \mathrm{~g}$ per sample bottle) by the supplier and kept prior to use in a cooling chest set at $4^{\circ} \mathrm{C}$ (Giang et al. 2011). However, the experiment adopted completely randomized experimental design in arranging twenty-four landrace pigs (8 weeks old) weighing approximately $16.50 \mathrm{~kg}$, into four different
Table 1: Composition of basal diet

\begin{tabular}{ll}
\hline Ingredients & $(\%)$ \\
\hline Wheat offal & 25.00 \\
Palm kernel cake & 55.00 \\
Groundnut cake & 15.00 \\
Limestone & 2.50 \\
Lysine & 0.10 \\
Methonine & 0.10 \\
Salt & 0.20 \\
Enzyme + toxin binder & 0.10 \\
Total & 100.00 \\
Calculated & \\
Crude protein & 18.00 \\
Metabolizable energy $(\mathrm{kcal} / \mathrm{kg})$ & 2600.00 \\
\hline
\end{tabular}

dietary treatment groups tagged T1-T4. Each group was replicated thrice, having two pigs per replicate. Dietary treatment was according to dietary treatment groups such that; T1 was control, T2 had 50g of LA, T3 received $50 \mathrm{~g}$ of GP and T4 had $50 \mathrm{~g}$ each of LA and GP $50 \mathrm{~kg}^{-1}$ diet. The pigs were fed $4 \%$ of their body weight with the treated diets every morning till the close of study even as their feeding troughs were cleaned of stale feeds (determined weights) daily before serving fresh feeds. More so, we managed and sampled the pigs in accordance with the extant provisions of the Ethical Committee on the Use of Animals for Experimentation of the University of Nigeria.

\section{Data Collection and Statistical Analysis}

The growth performance indices studied were: initial and weekly body weights $(\mathrm{kg})$ of test pigs, ascertained by trapping the animals in jute sacs and hung on the Avery ${ }^{\circledR}$ spring balance of $100 \mathrm{~kg}$ capacity used in evaluating their average daily weight gain (ADWG), as the change in weekly body weights per days of the week; the average daily feed intake (ADFI), measured as the difference between feed served to a replicate pen and remnants after $24 \mathrm{~h}$ per number of pigs in the replicate; feed conversion ratio (FCR), calculated as the quantity of feed consumed to the corresponding weight gained during the feeding period; feed cost $\mathrm{kg}^{-1}$ gain (FC), computed by the product of the cost of total feed intake and FCR. Moreover, body morphometric measurements were carried out on biweekly basis to determine the animals' height at whither (HW), chest girth (CG), body flank (BF), and body length (BL) in line with the Onyimonyi procedure for linear body measurements of pigs (Machebe et al. 2016). Data from the study were statistically analyzed in one-way analysis of variance using the SPSS version 22.0 such that significant treatment means were separated using the Duncan's new multiple range test set at 5\% probability level.

\section{RESULTS}

\section{Effect of Feeding Probiotics and Garlic Treated Diets on the Growth Performance of Pigs}

The growth indices of weaned piglets fed diets treated with probiotics LA and garlic (Table 2) indicated final body weights (FBW), ADFI, FC and FCR of the under-studied pigs to be significantly $(\mathrm{P}<0.05)$ different, without affecting their ADWG $(\mathrm{P}>0.05)$. However, Pigs on treated diets recorded high FBW values (T2, 46.13kg; T3, $44.63 \mathrm{~kg} ; \mathrm{T} 4,44.78 \mathrm{~kg}$ ) that were significantly different from control $(41.50 \mathrm{~kg})$. High ADFI of T1 (1.44kg) was 
Table 2: Growth indices of weaned piglets fed diets treated with garlic and probiotics

\begin{tabular}{lcccc}
\hline Parameters & T1 & T2 & T3 & T4 \\
\hline IBW $(\mathrm{kg})$ & $16.88 \pm 1.09$ & $16.88 \pm 0.13$ & $16.75 \pm 0.14$ & $16.50 \pm 1.44$ \\
FBW $(\mathrm{kg})$ & $41.50 \pm 2.40 \mathrm{~b}$ & $46.13 \pm 1.65 \mathrm{a}$ & $44.63 \pm 1.66 \mathrm{a}$ & $44.78 \pm 3.90 \mathrm{a}$ \\
ADWG $(\mathrm{kg})$ & $0.29 \pm 0.23$ & $0.35 \pm 0.29$ & $0.33 \pm 0.19$ & $0.34 \pm 0.24$ \\
ADFI $(\mathrm{kg})$ & $1.44 \pm 0.66 \mathrm{a}$ & $1.26 \pm 0.69 \mathrm{ab}$ & $1.25 \pm 0.05 \mathrm{ab}$ & $1.16 \pm 0.07 \mathrm{~b}$ \\
FCR & $4.97 \pm 0.39 \mathrm{a}$ & $3.60 \pm 0.23 \mathrm{ab}$ & $3.79 \pm 0.01 \mathrm{ab}$ & $3.41 \pm 0.24 \mathrm{~b}$ \\
FC $(\mathrm{N})$ & $220.22 \pm 17.61 \mathrm{a}$ & $159.52 \pm 10.19 \mathrm{~b}$ & $167.93 \pm 13.31 \mathrm{~b}$ & $151.10 \pm 10.94 \mathrm{~b}$ \\
\hline
\end{tabular}

a, b denotes means on same row that are significantly different at 5\% probability, IBW is initial body weight, FBW is final body weight, ADWG is average daily weight gain, ADFI is average daily feed intake, FCR is feed conversion ratio, FC is feed cost per kg gain, LA is Lactobacillus acidophilus, GP is garlic powder, T1 is control, T2 is $50 \mathrm{~g}$ of LA $50 \mathrm{~kg}^{-1}$ feed, T3 is $50 \mathrm{~g}$ of GP $50 \mathrm{~kg}^{-1}$ feed, T4 is $50 \mathrm{~g}$ each of LA and GP $50 \mathrm{~kg}^{-1}$ feed.

Table 3: Linear body morphometrism of pigs fed diets treated with probiotics and garlic

\begin{tabular}{lllll}
\hline Parameters $(\mathrm{cm})$ & $\mathrm{T} 1$ & $\mathrm{~T} 2$ & $\mathrm{~T} 3$ & $\mathrm{~T} 4$ \\
\hline Height at withers & $47.54 \pm 0.79 \mathrm{bc}$ & $53.00 \pm 1.05 \mathrm{a}$ & $49.02 \pm 0.77 \mathrm{~b}$ & $46.17 \pm 0.89 \mathrm{c}$ \\
Body flank & $52.50 \pm 1.09 \mathrm{ab}$ & $55.75 \pm 1.02 \mathrm{a}$ & $52.17 \pm 0.99 \mathrm{~b}$ & $53.29 \pm 1.34 \mathrm{ab}$ \\
Body length & $77.54 \pm 1.40 \mathrm{ab}$ & $81.08 \pm 1.54 \mathrm{a}$ & $78.96 \pm 1.18 \mathrm{ab}$ & $75.02 \pm 1.98 \mathrm{~b}$ \\
Chest girth & $67.46 \pm 2.04 \mathrm{~b}$ & $72.33 \pm 1.28 \mathrm{a}$ & $69.58 \pm 1.46 \mathrm{ab}$ & $65.02 \pm 1.30 \mathrm{~b}$ \\
\hline
\end{tabular}

a, b, c represents means on the same row that are significantly different at 5\% probability, LA is Lactobacillus acidophilus, GP is garlic powder, T1 is control, T2 is $50 \mathrm{~g}$ of LA $50 \mathrm{~kg}^{-1}$ feed, T3 is $50 \mathrm{~g}$ of GP $50 \mathrm{~kg}^{-1}$ feed, T4 is $50 \mathrm{~g}$ each of LA and GP $50 \mathrm{~kg}^{-1}$ feed

significantly different $(\mathrm{P}<0.05)$ from the least values of $\mathrm{T} 4$ $(1.16 \mathrm{~kg})$ across treatment groups. However, T2 and T3 recorded comparable ( $\mathrm{P}>0.05)$ ADFI values (1.26 and $1.25 \mathrm{~kg}$ ) that were statistically the same with ADFI records of T1 and T4. Nonetheless, FCR of T4 (3.41) was better $(\mathrm{P}<0.05)$ than $\mathrm{T} 1$ (4.97), while T2 (3.60) and T3 (3.79) shared statistical similarity $(\mathrm{P}>0.05)$ with FCR of $\mathrm{T} 1$ and T4. Moreover, T1 recorded highest FC ( $\$ 220.22)$ that differed considerably $(\mathrm{P}<0.05)$ from the low values of treated groups irrespective of the statistical similarity (P>0.05) among the treatments such that $\mathrm{T} 2$ recorded 159.52 while T3 and T4 had $\$ 167.93$ and $\$ 151.10$, respectively.

\section{Effect of Feeding Varying Levels of Probiotics and Garlic on the Body Morphometrism of Pigs}

The linear body measurements of pigs fed diets treated with probiotics and garlic as presented on Table 3 indicated that $\mathrm{HW}$ of $\mathrm{T} 2(53.00 \mathrm{~cm})$ was the best $(\mathrm{P}<0.05)$ among the pigs while the least statistical $(\mathrm{P}<0.05)$ value of $46.17 \mathrm{~cm}$ was recorded for T4. However, T1 had comparable ( $\mathrm{P}>0.05)$ HW scores $(47.54 \mathrm{~cm})$ with T3 $(49.02 \mathrm{~cm})$ and T4. The high BF measures of T2 $(55.75 \mathrm{~cm})$ were not different from $\mathrm{T} 1(52.50 \mathrm{~cm})$ and $\mathrm{T} 4(53.29 \mathrm{~cm})$, but higher than $\mathrm{T} 3$ $(52.17 \mathrm{~cm}) . \mathrm{BL}$ of $\mathrm{T} 2(81.08 \mathrm{~cm})$ were longer $(\mathrm{P}<0.05)$ than T4 $(75.02 \mathrm{~cm})$, while $\mathrm{T} 1(77.54 \mathrm{~cm})$ and $\mathrm{T} 3(78.96 \mathrm{~cm})$ recorded comparable $(\mathrm{P}>0.05) \mathrm{BL}$ measurements with $\mathrm{T} 2$ and T4. Meanwhile, CG of T2 $(72.33 \mathrm{~cm})$ was significantly higher than T1 $(67.46 \mathrm{~cm})$ and $\mathrm{T} 4(65.02 \mathrm{~cm})$, yet similar to T3 $(69.58 \mathrm{~cm})$. Even so, we observed the CG of T3 to be statistically the same with CG measures of T1, T2 and T4.

\section{DISCUSSION}

The amplified final body weights of pigs fed improved diets could be ascribed to the role of the test additives in stimulating better utilization of feed nutrients in the gastrointestinal tract (GIT) of the experimental animals. Particularly, we highlighted the protein-sparing proclivity of Lactobacillus to be a probable metabolic itinerary that endorsed the enhanced weights of treated pigs. Ezema (2013) claimed that Lactobacillus based probiotics customarily prefer sugar moieties as metabolic substrates thereby availing sufficient proteins for utilization in the GIT. Hence, we explained these riveted proteins to be vital in the manufacture of sufficient body tissues that translated to the acclaimed weights of treated pigs. In agreement with our findings, the discrete studies of Jeong et al. (2015) and Dowarah et al. (2018) reported increased body weights of pigs served dietary treatment with Lactobacillus acidophilus. Yet, trivial growths of pigs fed dietary inclusion of Lactobacillus acidophilus are available in independent scientific reports (Cao et al. 2016 Zimmermann et al. 2016). However, the present botanical treatment most likely improved the acclaimed weights of treated animals by exhibiting intrinsic antimicrobial features that conditioned their intestinal tracts to support better metabolism of nutrients than the control. Thus, garlic in the feed exerted appreciable inhibition against gut pathogens such that complacent intestinal features of the test pigs promoted considerable nutrient conversion to swine tissues. In support of our current supposition, Airaodion et al. (2020) presented garlic to stall the activities and proliferation of pathogenic gram negative Escherichia coli, Salmonella typhi and Coliform bacillus So, present findings are consistent with the increased weights of weaned pigs observed when their feeds received dietary treatment with garlic (Batiha et al. 2020; Chen et al. 2021). Similar to our current results, the report of Ghosh et al. (2010) claimed that garlic as a feed conditioner did not influence the body weights but reduced feed intake and improved feed conversion efficiency of young animals.

Meanwhile, the present phytomicrobial dietary treatment (T4) exploited intestinal features associated with feed palatability and nutrient transformation in the test pigs. Allicin of garlic was indicated to be responsible for the unique irritant flavor of the Allium spice (Macpherson et al. 2005) which instigated significant loatheness in the feeding behavior of weaned pigs reported by Onyimonyi and Omeje (2013). Consequently, the subsisting experiment suggested the spiciness of garlic to have affected feed delectableness and possible ingestion in the pigs served the phytomicrobial dietary treatment thereby reducing their feed intake. There are purported claims of reduced feed intake of swine and poultry placed on dietary treatment with garlic powder (Onyimonyi et al. 2012; 
Onyimonyi and Omeje 2013). However, we found that feed intake of young pigs was not affected by dietary garlic even if they had better feed efficiency than the control (Yan and Kim 2013).

Furthermore, we described the role played by garlic spice in contributing to the superior feed conversion efficiency recorded for pigs on the phytomicrobial dietary treatment (T4) to be the capacity of garlic's allicin to stimulate increased hind gut activities in the pigs to support adequate assimilation of nutrient-chemicals. The effect of dietary nutrients on the distal gut is well explained in credible literature (Qaisrani et al. 2015) even as Onyimonyi and Omeje (2013) made annotations of the significant effect of garlic's allicin in activating the transient receptor potentials (TRPs) that conferred the unique pungent taste stimulus of garlic through the neurotransmitters in the mouth of treated pigs. Hence, we postulated these pain sensing neurons implicated in TRP activation to have initiated concurrent neural stimulation of the animals' hind gut to sponsor increased nutrient metabolism via the hypothalamo-pituitary gut axis. In complacent agreement with our proposition, independent studies of Han et al. (2017) and Rabelo-Ruiz et al. (2021) reported enhanced activities in the gut end of animals they placed on dietary treatment with garlic. Nonetheless, improved feed conversion efficiency was observed in weaned pigs fed diets improved with garlic spice (Yan et al. 2012) even with the contrasting report of Suleria et al. (2015), that highlighted the efficiency of nutrient conversion in garlic treated pigs to be unaffected.

This diminution in the quantity of feed consumed by animals on the phytomicrobial treatments (T4) could be explained to implicate the test lactic acid bacteria in stimulating intestinal production of short chained volatile fatty acids (SCVFA) that served the superfluous energy generation in the gut cells. We found scientific reports that associated increased SCVFA production with the activities of lactic acid bacillus bacteria in the gut (Qiao et al. 2015; Perez et al. 2016). These extra endogenous energy moieties probably contributed to the energy fulfillment required of the test pigs during nutrient metabolism such that the animals consumed less feed to attain satiety. Logical elucidation of energy score as chief determinants of feed intake in weaned barrows was presented by Oresanya et al. (2008). So, the reduced feed intake observed in grower pigs fed diets improved with Lactobacillus agrees with our present suggestion (Dowarah et al. 2017). However, we found reports of improved feed intake in pigs fed dietary probiotic treatment using Lactobacillus acidophilus (Perez et al. 2016; Dowarah et al. 2018)

Meanwhile, Lactobacillus acidophilus of the composite phytomicrobial treatment (T4) played supportive roles in amplifying the pigs' intestinal features to guarantee their acclaimed feed conversion efficiency. The aptitude of Lactobacillus based probiotics to influence gut features for better feed conversion was credited to the ability of the non-protein exudates resulting from their possible attachments to the gut to excite concomitant digestive secretions that improved efficient nutrient conversion in the host (Betancur et al. 2020; Arsene et al. 2021). Therefore, these non-protein complexes from test Lactobacillus acidophilus could have triggered increased digestive secretions central to incorporation of dietary constituents in the test pigs. Apposite swine studies that reported improved feed efficiency of weanling pigs using dietary treatment with Lactobacillus acidophilus were consistent with our extant findings (Jeong et al. 2015; Perez et al. 2016; Tufarelli et al. 2017). Nevertheless, unaffected feed conversion ratio of weaned piglets was highlighted in the review report of Dowarah et al. (2017).

However, the existing study envisaged synergistic interaction between test materials of the phytomicrobial treatment, but our current findings showed neither antagonistic nor additive effects. The test materials independently affected intestinal features that encouraged improved performance of the treated pigs. We noted that some authors proposed better animal performance with Lactobacillus in combination with other growth promoting feed agents than when in use as lone dietary treatment (Zhao et al. 2018; Liu et al., 2020). Also, the symbiotic concept of using specific in-feed substrate serving as prebiotics to preferentially facilitate the growth of probiotic bacteria or support a favorable gut environment for probiotics action was explained as a potential approach for better performance in pigs on dietary probiotics treatment (Bhandari et al. 2010; Guerra-Ordaz et al. 2014). Nonetheless, superior feed conversion ratio with no resultant effect on feed intake of weanling pigs were reported for Lactobacillus acidophilus in combination with feed agents (Balasubramanian et al. 2017), whereas BarbaVidal et al. (2018) observed no significant differences in the growth performance of weaned pigs fed diets treated with composite probiotic blend of Lactobacillus species in the same experimental field. Interestingly, we also found scientific evidence on the increased body weights of weaned piglets served phytomicrobial dietary treatment with probiotics culture alongside garlic on the same experimental field (Satora et al. 2021). On the other hand, the costs of feed we offered to treated pigs in this study were cheaper than the control even as their body weights increased in line with the assertion of Dowarah et al. (2017), that improved weights and feed efficiency results in enhanced profitability of the farmer due to greater output and reduction in overhead costs of production.

The measures of body extremities of pigs on microbial dietary treatment showed significant superiority over the control group as the animals were taller and larger in body size. These improved linear growths were evidently proved in the pigs' height at withers and chest girth measurements. Chest girth is measured as the linear thoracic rib cage circumference directly behind the forelegs while height at withers measures the shoulder of the animal to the ground platform immediately after the dew claw. These biometric measurements were reported as key determinants of pigs' live weight, growth rate and overall productive performance (Tissopi et al. 2019). Lactobacillus acidophilus could have contributed to the increased body size of pigs on the probiotics treatment by improving their intestinal epithelia barrier for enhanced gut absorption and assimilation of dietary constituents. Superior gut barrier was associated with improved linear growth of weaned pigs fed Lactobacillus acidophilus based probiotic dietary treatments (Qiao et al. 2015; Cao et al. 2016). However, improved chest girths and height at withers of grower pigs fed microbial dietary treatment with Lactobacillus acidophilus were reported in agreement with present 
findings (Zhao and Kim 2015; Cao et al. 2016). Nonetheless, some authors noted that dietary probiotic treatment with Lactobacillus acidophilus did not improve the linear growth of pigs (Ahmed et al. 2014).

\section{Conclusion}

Phytomicrobial dietary treatment with $50 \mathrm{~g}$ each of Lactobacillus acidophilus and garlic powder per $50 \mathrm{~kg}$ of feed improved growth performance indices of pigs in our present study as it was obvious in the better feed conversion ratio and reduced feed intake of pigs on composite dietary treatment than the control, hence suggesting improved nutrient utilization in the treated pigs. Also, microbial dietary treatment with $50 \mathrm{~g}$ of Lactobacillus acidophilus per $50 \mathrm{~kg}$ of basal feed supported superior body morphometrism of growing pigs as was evident in their enhanced chest girths and height at withers measurements which are proven estimates of live weight and growth in swine production hence their selection as suitable dietary treatment in advancing linear body morphometrism of pigs. Thus, we recommend our phytomicrobial dietary treatment with Lactobacillus acidophilus and garlic powder to be widely adopted by pig farmers in producing safe pig products for the growing human consuming populace.

\section{Acknowledgement}

We wish to express our profound gratitude to Prof. A.E. Onyimonyi of the Department of Animal Science, University of Nigeria Nsukka, for the in-depth scientific collaboration he proffered that was central to the study. In sincere gratitude, we acknowledge the prowess he established in proofreading the final draft of the manuscript.

\section{Author's Contribution}

The authors significantly contributed equally to the research. JIU designed and performed the experiment alongside associated data collection, the analysis and interpretation of results. CAN and CED offered extensive dissertation of experimental data by elucidating critical theories and concepts central to the research. CED wrote the manuscript while all the authors read, edited and approved the final draft of the manuscript.

\section{REFERENCES}

Adeola AC, Saidu O, Oseni SO and Omitogun OG, 2013. Morphological characterization of indigenous and crossbred pigs in rural and peri-urban areas of Southwestern Nigeria. Open Journal of Animal Sciences 3: 230-235. https://doi.org/ 10.4236/ojas.2013.33034

Ahmed ST, Hoon J, Mun HS and Yang CJ, 2014. Evaluation of Lactobacillus and Bacillus-based probiotics as alternatives to antibiotics in enteric microbial challenged weaned piglets. African Journal of Microbiology Research 8: 96-104. https://doi.org/10.5897/AJMR2013.6355

Airaodion AI, Ngwogu AC, Ngwogu KO, Ekenjoku JA and Megwas AU, 2020. Pharmacotherapeutic activity of Allium sativum (garlic) bulb against gram-positive and gramnegative bacteria. Asian Journal of Research in Infectious Diseases 3: 22-27. https://doi.org/10.9734/AJRID/2020/ v3i330128

Arsene M, Davares A, Andreevna S, Vladimirovich E, Carime B, Marouf R and Khelifi I, 2021. The use of probiotics in animal feeding for safe production and as potential alternatives to antibiotics. Veterinary World 14: 319-328. https://doi.org/ 10.14202/vetworld.2021.319-328

Balasubramanian B, Lee SI and Kim IH, 2017. Inclusion of dietary multispecies probiotic on growth performance, nutrient digestibility, meat quality traits, faecal microbiota and diarrhoea score in growing-finishing pigs. Italian Journal of Animal Science. https://doi.org/10.1080/1828051X. $\underline{2017.1340097}$

Barba-Vidal E, Martin-Orue SM and Castillejos L, 2018. Are we using probiotics correctly in post-weaning piglets? Animal 12: 2489-2498. https://doi.org/10.1017/S1751731118000 $\underline{873}$

Batiha GE, Beshbishy AM, Wasef LG, Elewa YH, Al-Sagan AA, Abd El-Hack ME, Taha AE, Abd-Elhakim YM and Devkota HP, 2020. Chemical constituents and pharmacological activities of garlic (Allium sativum L.): A review. Nutrients 12: 872. https://doi.org/10.3390/nu12030872

Betancur C, Martinez Y, Merino-Guzman R, Hernandez-Velasco $\mathrm{X}$, Castillo R, Rodriguez R and Tellez-Isaias G, 2020. Evaluation of oral administration of Lactobacillus plantarum CAM6 strain as an alternative to antibiotics in weaned pigs. Animals 10: 1218. https://doi.org/10.3390/ani10071218

Bhandari SK, Opapeju FO, Krause DO and Nyachoti CM, 2010 Dietary protein level and probiotic supplementation effects on piglet response to Escherichia coli K88 challenge: Performance and gut microbial population. Livestock Science 133: 185-188. https://doi.org/10.1016/j.livsci.2010. 06.060

Blavi L, Sola-Oriol D, Llonch P, Lopez-Verge S, Martin-Orue SM and Perez JF, 2021. Management and feeding strategies in early life to increase piglet performance and welfare around weaning: A review. Animals 11: 302. https://doi.org/ 10.3390/ani11020302

Cao S, Wang L, Jiao L, Lin F, Xiao K and Hu C, 2016. Effects of diosmectite-Lactobacillus acidophilus on growth performance, intestine microbiota, mucosal architecture of weaned pigs. Animal Feed Science and Technology 220: 180-186. https://doi.org/10.1016/j.anifeedsci.2016.08.012

Chen J, Wang F, Yin Y and Ma X, 2021. The nutritional applications of garlic (Allium sativum) as natural feed additives in animals. Peer J 9: e11934. https://doi.org/10. 7717/peerj.11934

Dowarah R, Verma A and Agarwal N, 2017. The use of lactobacillus as an alternative of antibiotic growth promoters in pigs: A review. Animal Nutrition 3: 1-6. https://doi.org/ 10.1016/j.aninu.2016.11.002

Dowarah R, Verma AK, Agarwal N, Singh P and Singh BR, 2018. Selection and characterization of probiotic lactic acid bacteria and its impact on growth, nutrient digestibility, health and antioxidant status in weaned piglets. PLoS ONE 13: e0192978. https://doi.org/10.1371/journal.pone.0192978

European Food Safety Authority [EFSA], 2017. Guidance on the assessment of the efficacy of feed additives. EFSA Journal 15: e05022. https://doi.org/10.2903/j.efsa.2017.5022

Ezema C, 2013. Probiotics in animal production: A review. Journal of Veterinary Medicine and Animal Health 5: 308316. https://doi.org/10.5897/jvmah2013.0201

Ghosh S, Mehla RK, Sirohi SK and Roy B, 2010. The effect of dietary garlic supplementation on body weight gain, feed intake, feed conversion efficiency, faecal score, faecal coliform count and feeding cost in crossbred dairy calves Tropical Animal Health and Production 42: 961-968. https://doi.org/10.1007/s11250-009-9514-5

Giang HH, Viet TQ, Ogle B and Lindberg JE, 2011. Effects of supplementation of probiotics on the performance, nutrient digestibility and faecal microflora in growing-finishing pigs. Asian-Australasian Journal of Animal Sciences 24: 655-661. https://doi.org/10.5713/ajas.2011.10238

Guerra-Ordaz A, Gonzalez-Ortiz G, La Regione RM, Woodward M, Collins J, Perez JF and Martin-Orue SM, 2014. Lactulose 
and Lactobacillus plantarum, a potential complementary symbiotic to control postweaning colibacillosis in piglets. Applied and Environmental Microbiology 80: 4879-4886. https://doi.org/10.1128/AEM.00770-14

Han GG, Lee JY, Jin GD, Park J, Choi YH, Chae BJ, Kim EB and Choi YJ, 2017. Evaluating the association between body weight and the intestinal microbiota of weaned piglets via rRNA sequencing. Applied Microbiology and Biotechnology 101: 5903-5911. https://doi.org/10.1007/ s00253-017-8304-7

Jeong J, Kim J, Lee S and Kim I, 2015. Evaluation of Bacillus subtilis and Lactobacillus acidophilus probiotic supplementation on reproductive performance and noxious gas emission in sows. Annals of Animal Science 15: 699709. https://doi.org/10.1515/aoas-2015-00718

Kumari A, Dutt T, Kumar A, Verma M and Tiwari R, 2020. Evaluation of Morphometric measurements to estimate body weight in crossbred Landly pigs (Landrace-Desi). Journal of Animal Research 10: 1099-1102. https://doi.org/10.30954/ 2277940X.06.2020.33

Liu X, Kim SH and Kim IH, 2020. Effects of the combination of multistrain probiotics and Castanea crenata shell extract on growth performance, nutrient digestibility, faecal microbial shedding, meat quality, noxious gas emissions and blood parameters in finishing pigs. Livestock Science 240: 104185. https://doi.org/10.1016/j.livsci.2020.104185

Machebe NS, Ezekwe AG, Okeke GC and Banik S, 2016. Path analysis of body weight in grower and finisher pigs. Indian Journal of Animal Research 50: 794-798. https://doi.org/ 10.18805/ijar.11319

Macpherson LJ, Geierstanger BH, Viswanath V, Bandell M, Eid SR, Hwang S and Patapoutian A, 2005. The pungency of garlic: Activation of TRPA1 and TRPV1 in response to allicin. Current Biology 15: 929-934. https://doi.org/10.1016 j.cub.2005.04.018

Morenikeji OB, Ogunshola OJ, Adu OA, Aro SO and Chineke CA, 2019. Genotype and sex effects on the performance characteristics of pigs. International Journal of Livestock Production 10: 127-134. https://doi.org/10.5897/IJLP2015. $\underline{0254}$

NRC, 2012. Nutrient Requirements of Swine, $11^{\text {th }}$ Ed. National Academy Press, Washington DC

Obayelu AE, Ogunmola OO and Sowande OK, 2017. Economic analysis and the determination of pig production in Ogun State, Nigeria. Agricultura Tropica et Subtropica 50: 61-70. https://doi.org/10.1515/ats-2017-0007

Onyenucheya CO and Nnamchi HC, 2018. Diurnal and annual mean weather cycles over Nsukka, Nigeria during 2010/2011. Nigerian Journal of Technology 37: 519-524. https://doi.org/10.4314/njt.v37i2.31

Onyimonyi AE and Omeje MU, 2013. Bioevaluation of garlic on growth, haematological and serum characteristics of growing pigs. African Journal of Biotechnology 12: 40394043. https://doi.org/10.5897/AJB2012.3035

Onyimonyi AE, Chukwuma PC and Igbokwe C, 2012. Growth and hypocholestrolemic properties of dry garlic powder (Allium sativum) on broilers. African Journal of Biotechnology 11: 2666-2671. https://doi.org/10.5897/AJB 11.2877

Oresanya TF, Beaulieu AD and Patience JF, 2008. Investigation of energy metabolism in weanling barrows: The interaction of dietary energy concentration and daily feed intake. Journal of Animal Science 86: 348-363. https://doi.org/10.2527/jas. 2007-0009

Perez SL, Lalles JP and Suescun JP, 2016. Effect of probiotic strain addition on digestive organ growth and nutrient digestibility in growing pigs. Revista Facultad Nacional de Agronomia 69: 7911-7918. https://doi.org/10.15446/rfna. v69n2.59136
Plavec TV and Berlec A, 2020. Safety aspects of genetically modified lactic acid bacteria. Microorganisms 8: 297. https://doi.org/10.3390/microorganisms 8020297

Pomar C and Remus A, 2019. Precision pig feeding: A breakthrough toward sustainability. Animal Frontiers 9: 5259. https://doi.org/10.1093/af/vfz006

Qaisrani SN, Van Krimpen MM, Kwakkel RP, Verstegen MWA and Hendriks WH, 2015. Dietary factors affecting hindgut protein fermentation in broilers: A review. World's Poultry Science Journal 71: 139-160. https://doi.org/10.1017/S0 043933915000124

Qiao JY, Li HH, Wang ZX and Wang WJ, 2015. Effects of Lactobacillus acidophilus dietary supplementation on the performance, intestinal barrier function, rectal microflora and serum immune function in weaned piglets challenged with Escherichia coli lipopolysaccharide. Antonie van Leeuwenhoek 107: 883-891. https://doi.org/10.1007/s1048 2-015-0380-Z

Rabelo-Ruiz M, Teso-Perez C, Peralta-Sanchez JM, Ariza JJ, Martin-Platero AM, Casabuena-Rincon O, Vazquez-Chas P, Guillamon E, Aguinaga-Casanas MA, Maqueda M, Valdivia E, Banos A and Martinez-Beuno M, 2021. Allium extract implements weaned piglet's productive parameters by modulating distal gut microbiota. Antibiotics 10: 269. https://doi.org/10.3390/antibiotics10030269

Sanchez CJ, Martinez-Miro S, Ariza JJ, Madrid J, Orengo J, Aguinaga MA, Banos A and Hernandez F, 2020. Effect of alliaceae extract supplementation on performance and intestinal microbiota of growing-finishing pig. Animals 10 1557. https://doi.org/10.3390/ani1091557

Satora M, Rzasa A, Rypula K and Ploneczka-Janeczko K, 2021. Field evaluation of the influence of garlic extract and probiotic cultures on sows and growing pigs. Medycyna Weterynaryjna 77: 21-29. https://doi.org/10.21521/mw.6447

Schubert DC, Chuppava B, Witte F, Terjung N and Visscher C, 2021. Effect of two different biochars as a component of compounded feed on nutrient digestibility and performance parameters of growing pigs. Frontiers in Animal Science 2: 633958. https://doi.org/10.3389/fanim.2021.633958

Suleria HAR, Butt MS, Khalid N, Sultan S, Raza A, Aleem M and Abbas M, 2015. Garlic (Allium sativum): Diet based therapy of $21^{\text {st }}$ century- a review. Asian Pacific Journal of Tropical Disease 5: 271-278. https://doi.org/10.1016/S2222-1808 (14)60782-9

Suryanarayana MV and Durga S, 2018. Role of phytogenic feed additives in swine production- a review. International Journal of Environment, Agriculture and Biotechnology 3: 1071. https://doi.org/10.22161/ijeab/3.3.46

Tissopi M, Bordoloi JP, Saharia J and Kro R, 2019. A study of body weight and its relation with linear body measurements in piglets fed different feed formulation. Agricultura Science Digest 39:142-148. https://doi.org/10.18805/ag.D$\underline{4888}$

Tufarelli V, Crovace AM, Rossi G and Laudadio V, 2017. Effect of a dietary probiotic blend on performance, blood characteristics, meat quality and feacal microbial shedding in growing-finishing pigs. South African Journal of Animal Science 47: 875-882. https:/doi.org/10.4314/sajas.v47i6.15

Umeh J, Ogbanje C and Adejo M, 2015. Technical efficiency analysis of pig production: A sustainable animal protein augmentation for Nigerians. Journal of Advanced Agricultural Technologies 2: 19-24. https://doi.org/10 12720/joaat.2.1.19-24

United Nations Department of Economic and Social Affairs, Population Division [UNDESA], 2019. World population prospects 2019: Highlights. ST/ESA/SER.A/423. https://creativecommons.org/licences/by/3.0/igo/legalcode

Upadhaya SD and Kim IH, 2017. Efficacy of phytogenic feed additive on performance, production and health status of 
Int J Vet Sci, 2022, 11(2): 257-263.

monogstric animals: A review. Annals of Animal Science 17: 929-948. https://doi.org/10.1515/aoas-2018-0079

Wang Y, Zhou J, Wang G, Cai S, Zeng X and Qiao S, 2018. Advances in low-protein diets for swine. Journal of Animal Sciences and Biotechnology 9: 60. https://doi.org/10.1186/ s40104-018-0276-7

Widayati TW, Rahayu BW, Rahardjo DD and Santoso B, 2018. The utilization of agricultural and food industry wastes as feed of grower pigs in Manokwari Regency West Papua. Animal Production 20: 165-172. https://doi.org/10.20884/ 1.jap.2018.20.3.723

Yan L and Kim IH, 2013. Effect of dietary supplementation of fermented garlic powder on growth performance, apparent total tract digestibility, blood characteristics and faecal microbial concentration in weanling pigs. Journal of Animal Physiology and Animal Nutrition 97: 457-464. https://doi.org/10.1111/j. 1439-0396.2012.86.x

Yan L, Meng QW and Kim IH, 2012. Effects of fermented garlic powder supplementation on growth performance, nutrient digestibility, blood characteristics and meat quality in growing-finishing pigs. Animal Science Journal 83: 411417. https://doi.org/10.1111/j.1740-0929.2011.00973.x

Zhao P, Zhang Z, Lan R, Li T and Kim IH, 2018. Comparison of efficacy of lactic acid bacteria complex and Enterococcus 7134 in weanling pigs. Journal of Applied Animal Research 46: 888-892. https://doi.org/10.1080/09712119.2017.1420655

Zhao PY and Kim IH, 2015. Effect of direct-fed microbial on growth performance nutrient digestibility, fecal noxious gas emission, fecal microbial flora and diarrhea score in weanling pigs. Animal Feed Science and Technology 200: 86-92. https://doi.org/10.1016/j.anifeedsci.2014.12.010

Zimmermann JA, Fusari ML, Rossler E, Blajman JE, RomeroScharpen A, Astesana DM, Olivero CR, Berisvil AP, Signorini ML, Zbrun MV, Frizzo LS and Soto LP, 2016. Effects of probiotics in swine growth performance: A metaanalysis of randomized controlled trials. Animal Feed Science and Technology 219: 280-293. https://doi.org/ $\underline{10.1016 / \text { j.anifeedsci.2016.06.021 }}$ 